\title{
Ground Water Modelling Through ModFlow
}

\author{
Saad Moeeni ${ }^{1 *}$ and Naved Ahsan ${ }^{2}$ \\ ${ }^{1}$ Department of Civil Engineering, Research Scholar, Jamia Millia Islamia University, India \\ ${ }^{2}$ Department of Electrical Engineering, Integral University, India
}

Submission: June22, 2017; Published: June 28, 2017

*Corresponding author: Saad Moeeni, Department of Civil Engineering, Research Scholar, Jamia Millia Islamia University, New Delhi, India

Abstract

The management of groundwater resources is now a great challenge for many countries of the world at present times groundwater modelling has been an effective way to address this challenge .presently for Groundwater modelling there are number of modeling software are available to simulate groundwater flow among them modeling software MODFLOW is used to determine the interaction between the surface water and groundwater and to develop a model for the study area.

\section{Introduction}

MODFLOW is designed to simulate aquifer system in which [1] saturated flow condition exist [2]. Darcy's

Law applies [3] the Density of groundwater is constant [4] the principal direction of horizontal hydraulic conductivity or transmissivity do not vary within the system. These conditions are met for many aquifers

Systems for which there is an interest in analysis of groundwater flow and contaminant movement for these systems the mathematical equations are solved using numerical codes such as MODFLOW, FEEFLOW.

$\partial / \partial \mathrm{x}[\mathrm{kxx} \delta \mathrm{h} / \delta \mathrm{x}]+\delta / \delta \mathrm{x}[\mathrm{kyy} \delta \mathrm{h} / \delta \mathrm{y}]+\delta / \delta \mathrm{z}[\mathrm{kzz} \delta \mathrm{h} / \delta \mathrm{z}]+\mathrm{w}=\mathrm{Ss}$ $\delta \mathrm{h} / \delta \mathrm{t} \ldots \ldots \ldots \ldots \ldots . . .1$

Kxx, Kyy, Kzz are the value of hydraulic conductivity along $\mathrm{x}$, $\mathrm{y}, \mathrm{z}$ coordinate axis

$\mathrm{h}$ is potentiometric head

$\mathrm{w}$ is volumetric flux

Ss is specific storage

\section{Methodology}

\section{Modflow Input}

Base map: Visual MODFLOW support the use of base maps in all modulus of the program

Boundary condition:

Rainfall and evaporation data for the entire study area.
Groundwater level to define the initial and boundary condition and for calibration and validation.

Aquifer properties for horizontal and vertical hydraulic conductivities, specific yield and specific st-

Orage distribution for different layer.

Groundwater abstraction data.

The input file formats to be given to a model are point data (XYZ) ASCII files (.TXT, .ASC, .DAT), MS Access Database files (.MDB), MS Excel files (.XLS), ESRI Point files (.SHP), USGS DEM files (.DEM), Surfer grid files (.GRD), ESRI grid files (.GRD) and MapInfo grid files (.GRD).

\section{Output Visualization}

Prior to output visualization, customizing the run time settings for modflow, modpath and mt3d are necessary. When the engines are finished running, the model will be transferred to the output section, where the simulation results will be displayed. The velocity vectors, path lines, water table contours, concentration contours can be seen in 2D or 3D according to the selection.

\section{Model Calibration}

Every model must be calibrated before it can be used as a tool for predicting the behavior of a considered system. During the calibration phase, the initial estimates of model coefficients may be modified. The sensitivity analysis may be postponed until a numerical model and a code for its solution have been selected. In this section objectives of the calibration or history 
matching, the adjusted parameters/coefficients, the criterion of the calibration [e.g., minimizing the difference between observed and predicted water levels), the available data, the model calibration runs, etc., should be described.

\section{Results and Discussion}

Advantages of MODFLOW include numerous facilities for data preparation, the modular structure that allows it to be easily modified to adapt the code for a particular application, great flexibility in handling a wide range of complexity, easy exchange of data in standard form, extended worldwide experience, continuous development and availability of the source code. In addition to simulating groundwater flow, the scope of MODFLOW has been expanded to incorporate related capabilities such as solute transport and parameter estimation.

\section{Conclusion}

From the above discussion, Visual MODFLOW software is suitable [1]

1. To simulate and predict the aquifer conditions and to represent the natural groundwater flow in the environment, [2].
2. To forecast the outcome of future groundwater behavior, [3].

3. To simulate hydraulic heads and ground water flow rates within and across the boundaries of the system, [4].

4. To simulate the concentrations of substance dissolved in ground water [5].

\section{References}

1. Brown GO (2002) Henry Darcy and the making of a law. Water Resources Research 38(7):11-12.

2. Wang HF, MP Anderson (1982) Introduction to Ground water Modeling: Finite Difference and Finite element methods. WH Freeman and company, San Francisco, California, USA, pp. 237.

3. US EPA (1996) Soil Screening Guidance: Technical Background Document. OSWER. Washington, USA.

4. WCED (1987) Our Common Future: Report of the World Commission on Environment and Development, WCED, Switzerland.

5. A Das Gupta, Puspa R (1997) Sustainable groundwater resources development by A. DAS GUPTA \& PUSPA R. ONTA Hydrological Sciences-Joumal-des Sciences Hydrologiques 42(4): 565-582.

Your next submission with Juniper Publishers
will reach you the below assets
- Quality Editorial service
- Swift Peer Review
- Reprints availability
- E-prints Service
- Manuscript Podcast for convenient understanding
- Global attainment for your research
- Manuscript accessibility in different formats
( Pdf, E-pub, Full Text, Audio)
- Unceasing customer service
Track the below URL for one-step submission
https://juniperpublishers.com/online-submission.php

